\title{
Immunohistochemical Localization of Leptin and Leptin-Receptor Proteins in Different Tissues of Chinese Alligator, Alligator sinensis
}

\author{
HuaBin Zhang ${ }^{1,2}$, YaSen $\mathrm{Li}^{1}$, Tao Pan ${ }^{1}$, Peng Yan ${ }^{1}$, En Li ${ }^{1}$, Hui Xue ${ }^{1}$ and \\ XiaoBing $\mathbf{W u}^{1, *}$ \\ ${ }^{1}$ Anhui Province Key Laboratory for Conservation and Exploitation of Biological \\ Resource, College of Life Sciences, Anhui Normal University, Wuhu 241000, Anhui, \\ China \\ 2Jiangsu Key Laboratory for Bioresources of Saline Soils, Jiangsu Provincial \\ Key Laboratory of Coastal Wetland Bioresources and Environmental Protection, \\ Jiangsu Synthetic Innovation Center for Coastal Bio-agriculture, Yancheng Teachers \\ University, Yancheng, 224007, China
}

\begin{abstract}
Leptin is a multifunctional hormone encoded of the ob gene, plays an important role in food intake and energy homeostasis. Recent studies indicated that the role of leptin is much broader, such as the regulation of reproduction and hibernation. But so far the limited study of leptin and its receptor has investigated in Chinese alligator, Alligator sinensis. Therefore, we reported the presence and location of leptin and its receptor in different tissues of Chinese alligator by immunohistochemistry analysis. This study aims to access the possible effect of leptin in Chinese alligator. The results showed that immunoreactivity of leptin was observed in the adipocyte of white adipose tissue, the gastric gland of the stomach, the lamina propria of the intestine and the interstitial cell and seminiferous tubule of testis, leptin receptor staining was detected in the adipocyte of white adipose tissue, the gastric gland and submucosa of the stomach, the submucosa, muscular layer and intestine villi of the intestine, the granulose cell and follicular membrane cell of the ovary and the interstitial cell and seminiferous tubule of the testis. Moreover, we investigated seasonal changes of leptin in plasma of Chinese alligator by radioimmunoassay method. Our results demonstrated circulating leptin levels varied significantly over the season. Therefore, we hypothesize that leptin is involved in nutrient stores, absorption and utilization, and reproductive behavior of the Chinese alligator.
\end{abstract}

\section{INTRODUCTION}

L eptin is a $16 \mathrm{kDa}$ hormone, product of the ob gene. The precursor form of leptin contains 167 amino acids and it circulates as a 146 amino acid peptide. When leptin was secreted in blood, whose amino-terminal signal sequence containing 21 amino acid residues are cleaved (Zhang et al., 1994). Recently, leptin was considered as the regulator of food intake and body weight homeostasis (Zhang et al., 1994; Fischer et al., 2019), and other various functions such as reproduction, immune response, and hematopoiesis (Cioffi et al., 1996; Loffreda et al., 1998). Besides, the source of leptin has also been demonstrated in different tissues, including

\footnotetext{
Corresponding author: wuxb $@ a h n u . e d u . c n$ 0030-9923/2021/0006-2371 \$ 9.00/0

Copyright 2021 Zoological Society of Pakistan
}

adipocytes, placenta (Masuzaki et al., 1997), mammary glands (Smith-Kirwin et al., 1998), brain and pituitary (Morash et al., 1999), stomach (Irena et al., 2019), ovary (Sarkar et al., 2010), testis (Shklyaev et al., 2003), liver (Paolucci et al., 2001), skeletal muscle (Wang et al., 1998), olfactory (Baly et al., 2007), and nose (Taildeman et al., 2010). As a leptin binding protein, the leptin receptor (LR) was also discovered in various tissues, such as the hypothalamus (Leshan et al., 2006), pancreas (Paolucci et al., 2006), liver (Paolucci et al., 2006), thyroid gland (Sciarrillo et al., 2005), olfactory (Baly et al., 2007), nose (Taildeman et al., 2010), and ovary (Sarkar et al., 2010). LR was expressed in six isoforms, including LR-a, LR-b, LR-c, LR-d, LR-e and LR-f (Lee et al., 1996). According to the structural differences, the leptin receptor's isoforms were divided into two classes: long (LR-b) and short (LRa, LR-c, LR-d, LR-e, LR-f). Among all LR isoforms, LR-a and LR-b are considered to be functional, and they involved 
in the control of leptin signalling and the transport and degradation of leptin. The leptin receptor could modulate its leptin synthesis in rat adipose tissue (Zhang et al., 1997). Leptin could also exert a control on the expression of its receptor by a differential way in the hypothalamicpituitary-ovarian axis (Di Yorio et al., 2008).

Leptin plays an important role in the regulation of body weight, food intake and energy expenditure (Stephens et al., 1995). The synthesized leptin is secreted into the blood, and into the brain through the blood-brain barrier, presumably by a soluble transporter (Banks et al., 1996), to bind to leptin receptors in the hypothalamus (Tartaglia et al., 1995). Finally, leptin administration stimulates or inhibits the release of neurotransmitters, such as neuropeptide Y, cocaine and amphetamine-regulated transcript, and proopiomelanocortin, resulting in decreased food intake and increased activity in rodents (Ahima et al., 2000). And then increased fat mass and changes in endocrine system signals exert negative feedback on leptin synthesis and secretion (Ahima and Flier, 2000). The rate of leptin secretion and its plasma concentration is correlated with total mammalian adipose depots (Klein et al., 1996). Therefore, this hormone circulates through the organism as an internal signal indicating the size of body fat depots.

Recent studies have demonstrated that leptin acted evidently as one of the important regulators of puberty and reproduction (Cunningham et al., 1999; Díaz-Torga et al., 2001; Ahmadi et al., 2016). Leptin was implicated that can regulate the hypothalamic-pituitary axis, mainly through effects on the GnRH neuronal system. Additional study revealed the ability of intrahypothalamic infusion of leptin can stimulate GnRH release in vivo and the normalization of pulsatile $\mathrm{GnRH} / \mathrm{LH}$ secretion after central leptin administration in fasted rats (Watanobe, 2002). Leptin plays an important role in regulating reproduction in the infertile ob/ob mouse (Ahima et al., 2000). In mice, testicular weights and diameters of seminiferous tubules were significantly increased in the leptin injected group, and the present findings indicate that testicular functions and synthesis of testosterone increase after administration of leptin (Kus et al., 2005). Leptin can bring about a delay in testis summer regression in Podarcis sicula, playing a regulatory role in reproduction in this species (Putti et al., 2009). In the lizard, leptin levels in plasma, liver, and fat bodies fluctuated during the reproductive cycle, indicated that leptin might regulate reproductive function (Paolucci et al., 2001; Sun et al., 2018). Several pieces of evidience suggest that leptin can regulate the onset of puberty. Initiation of puberty in girls may occur when sufficient leptin concentrations are reached (Palmert et al., 1998). In female mice, leptin acts as a signal triggering puberty to influence the reproductive tract (Chehab et al., 1997).
Recently, the studies of leptin and its receptors mainly focus on mammalian species, and a few lizard and snake species in reptile (Denver et al., 2011; Putti et al., 2009; Paolucci et al., 2001, 2006; Spanovich et al., 2006; Sciarrillo et al., 2005; Muruzábal et al., 2002; Niewiarowski et al., 2000; Sun et al., 2018). However, the limited study of leptin and its receptor was investigated in the Chinese alligator (Alligator sinensis). Here, we reported the distribution of leptin and its receptors in several different tissues of the Chinese alligator by immunohistochemical analyses and seasonal fluctuations on circulating leptin in alligators by radioimmunoassay method. The aim is to discover the source and the target organ of leptin in different tissues, seasonal changes of leptin in the plasma of Chinese alligator, and to discuss the possible involvement of leptin in reproduction, energy homeostasis and hibernation.

\section{MATERIALS AND METHODS}

\section{Immunohistochemistry}

The testis, the spermaduct and the epididymis were removed from adult male alligators. The ovary, oviduct, stomach, intestines and white adipose tissue were collected from female alligators. All samples were fixed in Bouin's fixative for $24 \mathrm{~h}$. Then these tissues were stored in $70 \%$ ethanol until embedded in paraffin by conventional methodology, after which sections of $5 \mu \mathrm{m}$ were obtained with a rotary microtome. After dewaxing and rehydration, endogenous peroxidase was quenched with $3 \%$ hydrogen peroxide for $10 \mathrm{~min}$. Antigen retrieval was achieved through heat exposure of sections immersed in $0.01 \mathrm{M}$ citric acid buffer solution $(\mathrm{pH} 6.0)$ for $10 \mathrm{~min}$ at $95^{\circ} \mathrm{C}$ followed by a wash in phosphate-buffered saline at PBS $\mathrm{pH}$ 7.4. To prevent non-specific binding of antibodies, segments were incubated with 5\% normal goat serum for $20 \mathrm{~min}$. Segments were then incubated with the primary antibodies overnight at $4{ }^{\circ} \mathrm{C}$. Negative controls were designed by replacing primary antibodies with PBS. After the incubation period with primary antibodies and wash in PBS, the sections were incubated with the secondary antibody for $20 \mathrm{~min}$ and immunostained by SABC method (SA1022, Boster Company, China), finally, DAB (AR1022, Boster Company, China) was visualized. Tissues were counterstained with hematoxylin. After the sections were dehydrated, all slides were covered with the neutral balsam. Stained sections were examined under a light microscopic (Olympus BX61). The following antibodies were used in this study: rabbit polyclonal anti-human leptin antibody (BA1231, Boster Company, China, diluted 1:100 in antibody diluent), rabbit polyclonal anti-human Leptin receptor antibody (BA1233, Boster Company, China, diluted 1:100 in antibody diluent). 


\section{Radioimmunoassay}

Twenty adult Chinese alligators (ten females and ten males) were captured and kept alone in a pond. Blood samples were collected each two months from the vein of the tail. Plasma was obtained by $5000 \mathrm{r} / \mathrm{min}$ centrifugation for $10 \mathrm{~min}$ at $4^{\circ} \mathrm{C}(5804 \mathrm{R})$ and stored at $-40^{\circ} \mathrm{C}$ until use. All samples were sent to Yi Ji Shan Hospital to measure leptin concentration in plasma by professional workers. Leptin Radioimmunoassay Kit was bought from the Beijing North Institute of Biological Technology. The data were analyzed by an oneway ANOVA method with SPSS 25.0 programme.

\section{RESULTS}

Location of the leptin and its receptor in different tissues

Immunoreactivity of leptin in Chinese alligator was presented in Figure 1. Immunoreactivity of leptin was observed in the white adipose tissue (Fig. 1A). The study of gastric sections of the stomach immunostained for leptin showed immunoreactivity on the gastric gland of the mucosa (Fig. 1B). Moreover, immunohistochemistry of the intestine revealed leptin staining localized to lamina propria (Fig. 1C). In addition, leptin staining was detected in the interstitial cell, the supporting cell, spermatogonium, primary spermatocyte, secondary spermatocyte and spermatid of the testis (Fig. 1D, E), whereas the immunoreactivity was not observed in spermaduct, epididymis, ovary and oviduct.

Figure 2 shows immunoreactivity of the leptin receptor. Leptin receptor staining was detected in the adipocytes (Fig. 2A). The universal presence of the leptin receptor was observed in the intestine (Fig. 2B, C). Moreover, immunohistochemistry of the ovary revealed leptin staining localized to the granular cell and the membrane cells of the follicular (Fig. 2D). In addition, leptin receptor staining was presented in the gastric gland of the mucosa and submucosa of the stomach (Fig. 2E, F). The leptin receptor showed intense immunoreactivity on testis (Fig. 2F), such as the interstitial cell, the supporting cell, spermatogonium, primary spermatocyte, secondary spermatocyte and spermatid. However, the immunoreactivity was not examined in spermaduct, epididymis and oviduct.

\section{The seasonal changes of leptin in the plasma}

The seasonal changes of leptin in plasma of female and male Chinese alligators were listed in Table I. In A. sinensis, Leptin concentration in plasma ranged between 0.01 and $1.53 \mathrm{ng} \mathrm{ml}^{-1}$. The mean concentrations of leptin levels were $0.3796 \pm 0.04817 \mathrm{ng}$ $\mathrm{ml}^{-1}$ in females and $0.5644 \pm 0.06723 \mathrm{ng} \mathrm{ml}^{-1}$ in males.

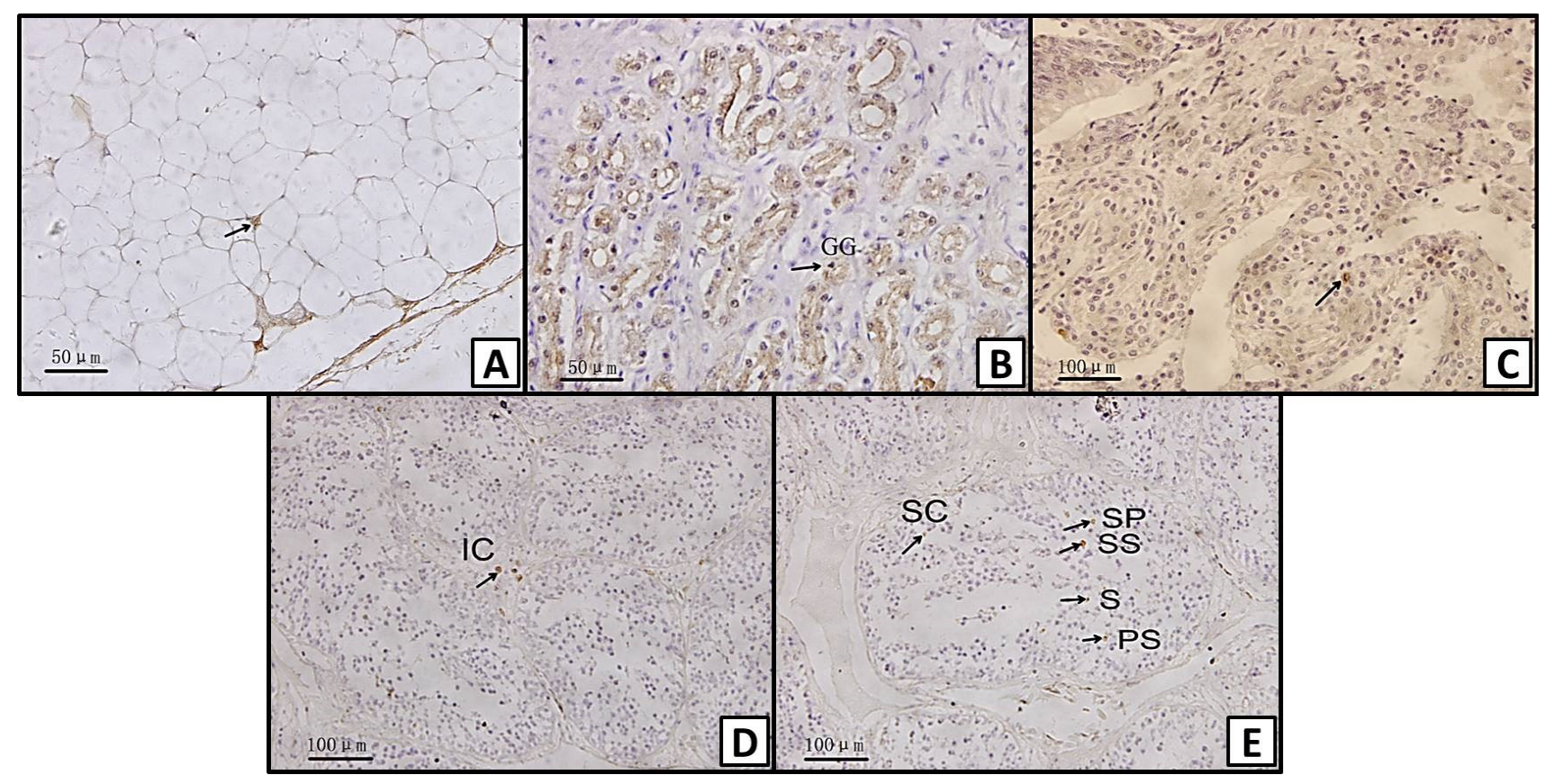

Fig. 1. Immunohistochemical localization of leptin in different tissues of Chinese alligator: A, adipocyte; B, gastric gland (GG) of the stomach; C, lamina propria of the intestine; D, interstitial cell (IC) of the testis; E, supporting cell (SC), spermatogonium (SP), primary spermatocyte (PS), secondary spermatocyte (SS), and spermatid (S) of the testis. Magnification: A, B, C = X400; $\mathrm{D}, \mathrm{E}=\mathrm{X} 200$. 


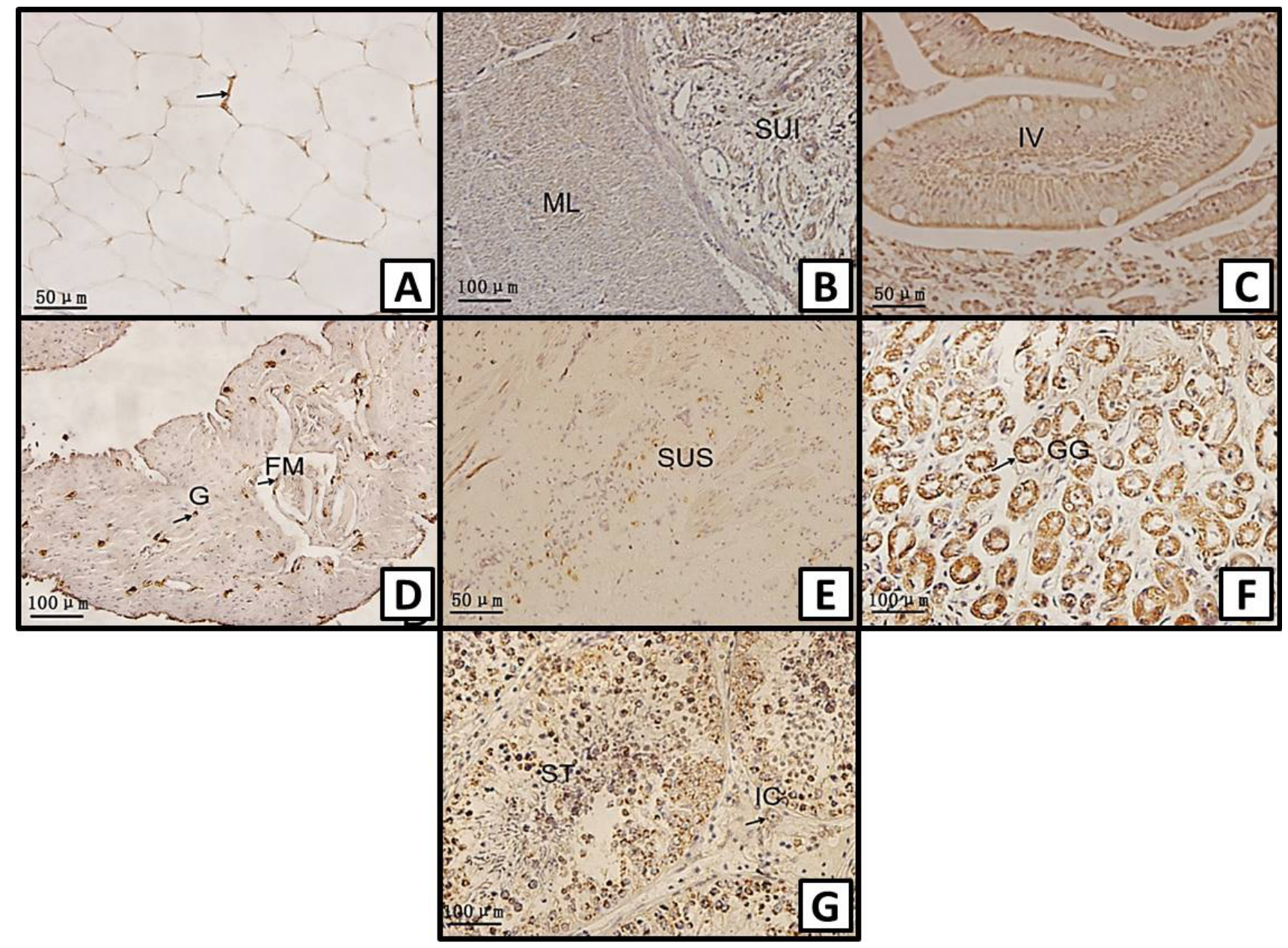

Fig. 2. Immunohistochemical localization of leptin receptor in different tissues of Chinese alligator: A, adipocyte; B, submucosa (SUI) and muscular layer (ML) of the intestine; C, intestine villi (IV) of the intestine; D, granulosa cell (G) and follicular membrane cell (FM) of the ovary; E, submucosa (SUS) of the stomach; F, gastric gland (GG) of the stomach; G, interstitial cell (IC), seminiferous tubule (ST) of the testis. Magnification: A, C, E $=$ X400; B, D, F, G = X200.

Circulating leptin levels varied significantly over the season in females $(\mathrm{df}=5, \mathrm{~F}=12.286, \mathrm{P}<0.01)$ and in males $(\mathrm{df}=5, \mathrm{~F}=25.144, \mathrm{P}<0.01)$ (Table I). Leptin concentrations in plasma of female Chinese alligator showed two peaks: one occurs in November, coinciding with the maximum fat accumulation with hibernation, whereas the second shorter peak occurs in July, coinciding with ovulatory period. Leptin concentrations decreased in May to the lowest level, however, its concentration in plasma of male Chinese alligators showed only one peak in January, which is consistent with the maximum fat accumulation with hibernation, and decreased in September to the lowest level (Fig. 3). Circulating leptin levels did not show the significant change between females and males in the same month except for May. In May, leptin concentration in plasma of the males was higher than that of the females.
No statistical difference between the males and the females was observed in the others.

Table I.- Leptin concentration in plasma of male and female Chinese alligator in different months.

\begin{tabular}{lc}
\hline Months & Leptin concentration $(\mathbf{n g} / \mathbf{m l})($ Mean \pm SE) \\
\hline January & $0.83 \pm 0.10$ \\
March & $0.67 \pm 0.10$ \\
May & $0.23 \pm 0.10$ \\
July & $0.24 \pm 0.04$ \\
September & $0.14 \pm 0.03$ \\
November & $0.61 \pm 0.09$ \\
All & $0.47 \pm 0.04$ \\
\hline
\end{tabular}




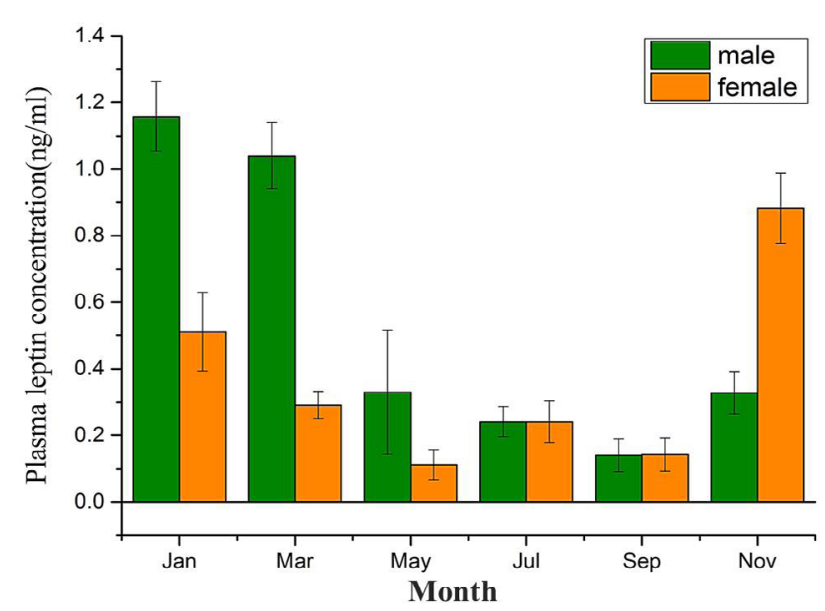

Fig. 3. The difference in leptin of male and female Chinese alligator in different months. (values are expressed as mean $\pm \mathrm{SE})$.

\section{DISCUSSION}

In this study, we reported the presence of leptin and its receptor in different tissues of Chinese alligator. Immunoreactivity of leptin was observed in the white adipose tissue. In the mammal, although the presence of immunoreactive leptin was reported in several fish tissues such as heart, brain and blood, surprisingly not in adipose tissue (Johnson et al., 2000; Fischer et al., 2019), leptin was mainly secreted in adipose tissue. The first description of leptin (mRNA and protein) was performed in the stomach of rat (Bado et al., 1998). In addition, the study of gastric sections of Chinese alligator immunostained for leptin showed intense immunoreactivity on the gastric gland of the mucosa. Immunoreactivity for leptin was found in the secretory granules of chief cells and an especial type of endocrine cell (Cinti et al., 2000). Leptin has been detected leptin in the human stomach (Sobhani et al., 2000). Recently, the presence of leptin was examined in the stomach of non-mammalian vertebrates, such as cartilaginous fish, teleost fish (Oncorhynchus mykiss, Dicentrarchus labrax and Carassius auratus), frog (Xenopus laevis), lizard (Podarcis hispanica), snake (Natrix maura) and chicken (Muruzábal et al., 2002; Gambardella et al., 2010; Russo et al., 2010). Moreover, immunohistochemistry in the intestine of Chinese alligator revealed leptin staining localized to lamina propria. Leptin was detected in the intestine of the fishes (Gambardella et al.,2010; Russo et al.,2010). In addition, leptin was detected in the interstitial cell, supporting cell, spermatogonium, primary spermatocyte, secondary spermatocyte and spermatid of the testis. In the pig, leptin was observed in Leydig cells and within seminiferous tubules of the mature testis (Rago et al., 2009). The presence of leptin mRNA was detected in the testis of Holstein cattle (Abavisani et al., 2009). The immunoreactivity was not observed in the spermaduct, the epididymis, the ovary or the oviduct, but was detected in all regions of mature epidilymides in the pig (Rago et al., 2009), in the bovine ovary (Sarkar et al., 2010), and in rat oviduct (Archanco et al., 2007). Using the Immunohistochemistry method, we found leptin synthesized locally in the white adipose tissue, stomach, intestine and testis.

Leptin receptor staining was detected in the adipocytes. As we all know, the adipose tissue is in charge of energy stores. Leptin receptor staining was presented in the gastric gland of the mucosa and submucosa of the stomach. In the human stomach, it existed in the basolateral membranes of fundic and antral gastric cells (Sobhani et al., 2000), and the extensive presence of leptin receptor was observed in the intestine. The expression of long form leptin mRNA was detected in the intestine of the pig (Lin et al., 2000). The stomach and intestine are in charge of energy absorption. Therefore, the present results implied that leptin may act as the directly regulator of energy depots and nutrient absorption area. Moreover, immunohistochemistry of the ovary revealed leptin staining localized to the granular cell and the follicular membrane cell. In Japanese black bear, the expression of leptin receptor protein was examined in ovary (Nakamura et al., 2009). Leptin receptor was detected in the bovine ovary (Sarkar et al., 2010). The secretion of sex steroids was regulated by granular cell and the follicular membrane cell in ovary. Our results showed that leptin has a direct effect in the modulation of ovarian steroidogenesis. The study of leptin receptor showed that intense immunoreactivity in different cells of the testis, including interstitial cell and seminiferous tubule (supporting cell, spermatogonium, primary spermatocyte, secondary spermatocyte and spermatid). In the pig, leptin receptor was detected in Leydig cells and within seminiferous tubules of mature testis (Rago et al., 2009). Sex steroids were mainly secreted in testicular interstitial cell. Supporting cell plays an important role in the development of sperm. Therefore, leptin may directly exert a control in proliferation, differentiation of germ cell and secretion of testicular steroidogenesis. However, immunoreactivity was not observed in the spermaduct, the epididymis or the oviduct. Leptin receptor was detected in all the epithelial cells of mature epididymides (Rago et $a l ., 2009$ ) and oviduct of the laying hen (Grzegorzewaka et al., 2008).

In summary, our results showed that adipose tissue, stomach, intestine, ovary and testis were the target organ of leptin, suggesting that leptin may directly regulate the functions of these organs, including nutrient stores, 
absorption and utilization, and the reproduction behavior, using both autocrine and paracrine mechanisms.

Additionally, leptin concentration in the plasma of the Chinese alligator was assessed by a RIA method, and displayed pronounced seasonal variations. Circulating leptin levels varied significantly over the season in female $(\mathrm{df}=5, \mathrm{~F}=12.286, \mathrm{P}<0.01)$ and in male $(\mathrm{df}=5, \mathrm{~F}=25.144$, $\mathrm{P}<0.01$ ). In $A$. sinensis, the average circulating leptin levels were $0.3796 \pm 0.04817 \mathrm{ng} \mathrm{ml}^{-1}$ in females and $0.5644 \pm 0.06723 \mathrm{ng} \mathrm{ml}^{-1}$ in males. The value was distinctly lower than the average leptin level in plasma in the fence lizards (Sceloporus undulatus) (Spanovich et al., 2006), Italian wall lizards (Podarcis sicula) (Paolucci et al., 2001), free-living European starlings (Sturnus vulgaris) (Kordonowy et al., 2010), normal weight human subjects (Sinha et al., 1998) and the adult rhesus monkey (Macaca mulatta) (Bodkin et al., 1996). In mammals, leptin is synthesized and secreted in the adipocytes. Circulating leptin levels are positively consistent with the amount of body fat (Florant and Porst, 2004). Leptin concentrations in plasma of female decreased to the lower level and in male decreased to the lowest level in September. When leptin levels decrease, food intake increases, metabolic rates reduce, energy consumption decreases and the final aim is to recovery body weight. Therefore, high levels of leptin may be responsible for the suppression of feeding behavior in Chinese alligator before winter. Before entering into hibernation in Chinese alligator, a lot of fat was stored to help Chinese alligator throughout the whole winter. Our result suggests that the autumn may represents the period of energy storage in Chinese alligator. And then the leptin rose rapidly to highest levels. In $A$. sinensis, the period of hibernation is from late October to mid-April. In early hibernation, the fat storage of Chinese alligator is to high levels. After entering winter hibernation, metabolic rates decrease rapidly. This is the period of hibernation, the fat accumulated in the autumn was used in the principal metabolic fuel (Chen et al., 2003). It implied that high levels of leptin may be responsible for the entering hibernation in Chinese alligator. During hibernation season, the Chinese alligator must reallocate finite energy stores. At this moment, the high plasma leptin concentrations may contribute to the maintenance of hypophagia, low exigent energy utilization and behavioral inactivity. The result is consistent with results of recent studies of leptin variation in seasonal vertebrates in raccon dog (Nyctereutes procyonoides) (Nieminen et al., 2002; Kitao et al., 2011). In mammals, leptin can control the amount of fat stored via inhibiting appetite which is secreted by adipocytes into the bloodstream and carried to the hypothalamic area by the Blood-Brain Barrier to inhibit the NPY release. NPY is known to stimulate appetite. Hence, the final leptin effect is to decrease food intake (Stephens et al., 1995).

Animals usually emerge from hibernation late in March or early in April when the temperature is over $16.4^{\circ} \mathrm{C}$, but do not forage until the temperature is over $20^{\circ} \mathrm{C}$ (Zhang et al., 2009). Foraging rate is associated positively with temperature (Wang et al., 1998). The peak time for egg laying occurs in early to mid-July (Chen et al., 2003). The increase of leptin concentration on July may be closely related to the spawning behavior of Chinese alligator. After laying eggs, the female alligator will protect the eggs and stop eating and moving. Animals stop foraging and enter hibernation in October to early November when the temperature falls below $18^{\circ} \mathrm{C}$. At the end of the winter dormancy of Chinese alligator, sexual glands develop quickly. In this period, the nutrition of the organism storage was transformed into the requirement of sexual glands development (Chen et al., 2003). After rising to the highest levels, leptin levels decreased gradually due to the consumption of the stored adipocytes. High leptin levels may play an important role in this event. In A. sinensis, the amount of lipid stored in the fat bodies increases during the winter dormancy, and may make leptin concentrations increase and the final effect is to increase energy consumption, providing for sexual glands development. In May, the courtship period of the Chinese alligator, leptin concentrations in plasma of the males decreased to the lower levels, was higher than the females. In this period, the males took up most of the time to courtship. The higher leptin levels can inhibit food intake, leptin therefore may play an important role in the courtship of the males. Hence most of the consumed nutrition providing for the courtship of the males may be supplied by the stored nutrition before the winter dormancy. However, Circulating leptin levels in the females reduced to the lower levels in the courtship period. When leptin levels decrease, food intake increases, metabolic rates reduce energy consumption decreases. Hence, sufficient nutrition was deposited to afford the necessary nutrition for reproduction in this period. After decreasing to the lower levels in May, leptin concentrations in plasma of female Chinese alligator rose to a short peak in July. Although the increase in males was not observed, circulating leptin concentrations was higher in July than that in September. It is well established that reproduction capacity depends on adequate nutrition and is associated with energy metabolism (Kirkwood and Aherne, 1985; Van der Spuy, 1985; Armstrong et al., 1987). Additionally, leptin serves to signal nutritional status to the nervous system and peripheral organs (Zhang et al., 1994). In the Chinese alligator, nutrition is one of the most important factors influencing reproductive capacity (Chen et al., 2003; Sun et al., 2018). In September, circulating leptin levels in the males decreased to the lowest levels, and in 
the females, it reduced to the lower levels. The results demonstrated that more adipocytes was stored in the males than that in the females, throughout the whole winter and was used by the reproduction behavior over the hibernation. Therefore, circulating leptin levels in the females increased to the highest levels in November, and in the males, it increased to the highest levels in January. Our results indicated that leptin may act as a regulator of reproduction behaviour. In mammals, malnourishment is related to hypogonadism and infertility (Brown, 1994). When animals with a deficit in food intake were injected with leptin, reproductive functions are restored (Barash et al., 1996; Chehab et al., 1996). Leptin was implied that it can regulate the hypothalamic-pituitary axis, mainly through effects on the GnRH neuronal system in mammals. In rats, leptin plays a role in gonadotropin secretion, and the infusion of leptin can stimulate GnRH release in vivo of fasted rats (Watanobe, 2002). The nutritional deficit in female inhibits GnRH release, and caused to decrease in the secretion of LH and finally led to anovulation and anestrus (Scaramuzzi et al., 2008). In the results of RIA and immunohistochemistry analysis, a high level of circulating leptin in the female of Chinese alligator during the reproduction period could be attributed to the gonadal action. Besides, leptin has a similar physiological function in endotherms and ectotherms. Our ultimate goal is to use leptin to manipulate age at maturity and to test fundamental questions in the evolution of life-history strategies.

\section{ACKNOWLEDGMENTS}

This study is financially supported by the Natural Science Foundation of China (No. 31872253, No. 31272337, No. 30770312), and the Key Laboratory of Biotic Environment and Ecological Safety in Anhui Province. We also greatly appreciate Mr. Chaolin Wang, Hongxing Zhu, Renping Wang for their assistance in collecting samples.

\section{Ethics statement}

This work was conducted as part of a population health assessment approved and supported by the Anhui Research Center for Chinese Alligator Reproduction and college of Life Sciences, Anhui Normal University. All procedures were approved by the Animal Ethics Committee of Anhui Normal University. All the handing and sampling were performed in compliance with standard vertebrate protocols and veterinary practices, and accordance with national and provincial Guidelines.

\section{Statement of conflicts of interest}

The authors disclose no potential conflicts of interest.

\section{REFERENCES}

Abavisani, A., Baghbanzadeh, A., Shayan, P., Tajik, P., Dehghani, H. and Mirtorabi, M., 2009. Leptin mRNA expresses in the bull reproductive organ. Vet. Res. Commun., 33: 823-830. https://doi. org/10.1007/s11259-009-9230-7

Ahima, R.S. and Flier, J.S., 2000. Leptin. Annu. Rev. Physiol., 62: 413-437. https://doi.org/10.1146/ annurev.physiol.62.1.413

Ahima, R.S., Saper, C.B., Flier, J.S. and Elmquist, J.K., 2000. Leptin regulation of neuroendocrine systems. Front. Neuroendocrinol., 21: 263-307. https://doi. org/10.1006/frne.2000.0197

Ahmadi, M., Pacala, N., Bencsik, I., Dronca, D., Stef, L., Nichita, I., Scurtu, M. and Milovanov, C., 2016. The importance of leptin in animal science. Scient. Pap. Anim. Sci. Biotechnol., 49: 134-139.

Archanco, M., Gómez-Ambrosi, J., Tena-Sempere, M., Frühbeck, G. and Burrell, M.A., 2007. Expression of leptin and adiponectin in the rat oviduct. $J$. Histochem. Cytochem., 55: 1027-1037. https://doi. org/10.1369/jhc.6A7128.2007

Armstrong, D.J. and Britt, J.H., 1987. Nutritionallyinduced anestrus in gilts: metabolic and endocrine changes associated with cessation and resumption of estrous cycles. J. Anim. Sci., 65: 508-523. https:// doi.org/10.2527/jas1987.652508x

Bado, A., Levasseur, S., Attoub, S., Kermorgant, S., Laigneau, J.P., Bortoluzzi, M.N., Moizo, L., Lehy, T., Guerre-Millo, M., Le Marchand-Brustel, Y. and Lewin, M.J., 1998. The stomach is a source of leptin. Nature, 394: 790-793. https://doi. org/10.1038/29547

Baly, C., Aioun, J., Badonnel, K., Lacroix, M.C., Durieux, D., Schlegel, C., Salesse, R. and Caillol, M., 2007. Leptin and its receptors are present in the rat olfactory mucosa and modulated by the nutritional status. Brain Res., 1129: 130-141. https://doi.org/10.1016/j.brainres.2006.10.030

Banks, W.A., Kastin, A.J., Huang, W., Jaspan, J.B. and Maness, L.M., 1996. Leptin enters the brain by a saturable system independent of insulin. Peptides, 17: 305-311. https://doi.org/10.1016/01969781(96)00025-3

Barash, I., Cheung, C., Weigle, D., Ren, H., Kabigting, E., Kuijper, J., Clifton, D. and Steiner, R., 1996. Leptin is a metabolic signal to the reproductive system. Endocrinology, 137: 3144-3147. https:// doi.org/10.1210/endo.137.7.8770941

Bodkin, N.L., Nicolson, M., Ortmeyer, H.K. and Hansen, B.C., 1996. Hyperleptinemia: relationship to 
adiposity and insulin resistance in the spontaneously obese rhesus monkey. Horm. Metab. Res., 28: 674678. https://doi.org/10.1055/s-2007-979876

Brown, B.W., 1994. A review of nutritional influences on reproduction in boars, bulls and rams. Reprod. Nutr. Develop., 34: 89-114. https://doi.org/10.1051/ rnd:19940201

Chehab, F., Lim, M. and Lu, R., 1996. Correction of the sterility defect in homozygous obese female mice by treatment with the human recombinant leptin. Nat. Genet., 12: 318-320. https://doi.org/10.1038/ ng0396-318

Chehab, F.F., Mounzih, K., Lu, R. and Lim, M.E., 1997. Early onset of reproductive function in normal female mice treated with leptin. Science, 275: 8890. https://doi.org/10.1126/science.275.5296.88

Chen, B.H., Hua, T.M., Wu, X.B. and Wang, C.L., 2003. Research on the Chinese alligator. Education Press of Sciences and Technology, Shanghai, China.

Cinti, S., Matteis, R.D., Picó, C., Ceresi E, Obrador, A., Maffeis, C., Oliver, J. and Palou, A., 2000. Secretory granules of endocrine and chief cells of human stomach mucosa contain leptin. Int. J. Obes. (Lond.), 24: 789-793. https://doi.org/10.1038/ sj.ijo.0801228

Cioffi, J.A., Shafer, A.W., Zupancic, T.J., Smith-Gbur, J., Mikhail, A., Platika, D. and Snodgrass, H.R., 1996. Novel B219/OB receptor isoforms: Possible role of leptin in hematopoiesis and reproduction. Nat. Med., 2: 585-589. https://doi.org/10.1038/ nm0596-585

Cunningham, M.J., Clifton, D.K. and Steiner, R.A., 1999. Leptin's actions on the reproductive axis: perspectives and mechanisms. Biol. Reprod., 60: 216-222. https://doi.org/10.1095/ biolreprod60.2.216

Denver, R.J., Bonett, R.M. and Boorse, G.C., 2011. Evolution of leptin structure and function. Neuroendocrinology, 94: 21-38. https://doi. org/10.1159/000328435

Di Yorio, M.P., Bilbao, M.G., Pustovrh, M.C., Prestifilippo, J.P. and Faletti, A.G., 2008. Leptin modulates the expression of its receptors in the hypothalamic-pituitary-ovarian axis in a differential way. J. Endocrinol., 198: 355-366. https://doi. org/10.1677/JOE-07-0622

Díaz-Torga, G.S., Mejia, M.E., González-Iglesias, A., Formia, N., Becú-Villalobos, D. and LacauMengido, I.M., 2001. Metabolic cues for puberty onset in free grazing Holstein heifers naturally infected with nematodes. Theriogenology, 56: 111-122. https://doi.org/10.1016/S0093-
$691 X(01) 00547-7$

Fischer, A.W., Cannon. B. and Nedergaard, J., 2020. Leptin: Is it thermogenic? Endocr. Rev., 41: 232260. https://doi.org/10.1210/endrev/bnz016

Florant, G.L. and Porst, H., 2004. Fat-cell mass, serum leptin and adiponectin changes during weight gain and loss in yellow-bellied marmots (Marmota flaviventris). J. Comp. Physiol. B: Biochem. Syst. environ. Physiol., 174: 633-639. https://doi. org/10.1007/s00360-004-0454-0

Gambardella, C., Gallus, L., Ravera, S., Fasulo, S., Vacchi, M. and Ferrando, S., 2010. First evidence of a leptin-like peptide in a cartilaginous fish. Anat. Rec. (Hoboken), 293: 1692-1697. https://doi. org/10.1002/ar.21238

Grzegorzewska, A.K., Paczoska-Eliasiewicz, H.E. and Rzasa, J., 2008. MRNA expression and immunocytochemical localization of leptin receptor in the oviduct of the laying hen (Gallus domesticus). Folia Biol., 56: 179-185. https://doi. org/10.3409/fb.56_3-4.179-185

Irena, K., Żaneta, P., Michał, N. and Wojciech Ł., 2019. Differences in leptin biosynthesis in the stomach and in serum leptin level between men and women. J. Gastroen. Hepatol., 34: 1922-1928. https://doi. org/10.1111/jgh.14688

Johnson, R.M., Johnson, T.M. and Londraville, R.L., 2000. Evidence for leptin expression in fishes. $J$. exp. Zool., 286: 718-724. https://doi.org/10.1002/ (SICI)1097-010X(20000601)286:7<718::AIDJEZ6>3.0.CO;2-I

Kasacka, I., Piotrowska, Ż., Niezgoda, M. and Łebkowski, W., 2019. Differences in leptin biosynthesis in the stomach and in serum leptin level between men and women. J. Gastroenterol. Hepatol., 34: 1922-1928. https://doi.org/10.1111/ jgh. 14688

Kirkwood, R.N. and Aherne, F.X., 1985. Energy intake, body composition and reproductive performance of the gilt. J. Anim. Sci., 60: 1518-1529. https://doi. org/10.2527/jas1985.6061518x

Kitao, N., Fukui, D., Shibata, H., Saito, M., Osborne, P.G. and Hashimoto, M., 2011. Seasonality and fasting effect in raccoon dog Nyctereutes procyonoides serum leptin levels determined by canine leptinspecific enzyme-linked immunosorbent assay. $J$. exp. Zool., 315: 84-89. https://doi.org/10.1002/ jez.649

Klein, S., Coppack, S.W., Mohamed-Ali, V. and Landt, M., 1996. Adipose tissue leptin production and plasma leptin kinetics in humans. Diabetes, 45: 984-987. https://doi.org/10.2337/diabetes.45.7.984 
Kordonowy, L.L., McMurtry, J.P. and Williams, T.D., 2010. Variation in plasma leptin-like immunoreactivity in free-living European starlings (Sturnus vulgaris). Gen. Comp. Endocrinol., 166: 47-53. https://doi.org/10.1016/j.ygcen.2009.09.005

Kus, I., Sarsilmaz, M., Canpolat, S., Yilmaz, B., Kelestimur, H., Akpolat, N. and Ozogul, C., 2005. Immunohistochemical, histological and ultrastructural evaluation of the effects of leptin on testes in mice. Arch. Androl., 51: 395-405. https:// doi.org/10.1080/014850190944375

Lee, G.H., Proenca, R., Montez, J.M., Carroll, K.M., Darvishzadeh, J.G., Lee, J.I. and Friedman, J.M., 1996. Abnormal splicing of the leptin receptor in diabetic mice. Nature, 379: 632-635. https://doi. org/10.1038/379632a0

Leshan, R.L., Bjornholm, M., Münzberg, H. and Myers, Jr. M.G., 2006. Leptin receptor signaling and action in the central nervous system. Obesity, 14: 208S-212S. https://doi.org/10.1038/oby.2006.310

Lin, J., Barb, C.R., Matteri, R.L., Kraeling, R.R., Chen, X., Meinersmann, R.J. and Rampacek, G.B., 2000. Long form leptin receptor mRNA expression in the brain, pituitary, and other tissues in the pig. Domest. Anim. Endocrinol., 19: 53-61. https://doi. org/10.1016/S0739-7240(00)00064-3

Loffreda, S., Yang, S.Q., Lin, H.Z., Karp, C.L., Brengman, M.L., Wang, D.J., Klein, A.S., Bulkley, G.B., Bao, C., Noble, P.W., Lane, M.D. and Diehl, A.M., 1998. Leptin regulates proinflammatory immune responses. Fed. Am. Soc. exp. Biol. J., 12: 57-65. https://doi.org/10.1096/fsb2fasebj.12.1.57

Masuzaki, H., Ogawa, Y., Sagawa, N., Hosoda, K., Matsumoto, T., Mise, H., Nishimura, H., Yoshimasa, Y., Tanaka, I., Mori, T. and Nakao, K., 1997. Nonadipose tissue production of leptin: Leptin as a novel placenta-derived hormone in humans. Nat. Med., 3: 1029-1033. https://doi. org/10.1038/nm0997-1029

Morash, B., Li, A., Murphy, P.R., Wilkinson, M. and Ur, E., 1999. Leptin gene expression in the brain and pituitary gland. Endocrinology, 140: 5995-5998. https://doi.org/10.1210/endo.140.12.7288

Muruzábal, F.J., Frühbeck, G., Gómez-Ambrosi, J., Archanco, M. and Burrell, M.A., 2002. Immunocytochemical detection of leptin in nonmammalian vertebrate stomach. Gen. Comp. Endocrinol, 128: 149-152. https://doi.org/10.1016/ S0016-6480(02)00072-2

Nakamura, S., Nishii, N., Yamanaka, A., Kitagawa, H., Asano, M., Tsubota, T. and Suzuki, M., 2009. Leptin Receptor (Ob-R) expression in the ovary and uterus of the wild Japanese black bear (Ursus thibetanus japonicus). J. Reprod. Dev., 55: 110115. https://doi.org/10.1262/jrd.20077

Nieminen, P., Mustonen, A.M., Asikainen, J. and Hyvärinen, H., 2002. Seasonal weight regulation of the raccoon dog (Nyctereutes procyonoides): Interactions between melatonin, leptin, ghrelin, and growth hormone. J. biol. Rhythms, 17: 155163. https://doi.org/10.1177/074873002129002447

Niewiarowski, P.H., Balk, M.L. and Londraville, R.L., 2000. Phenotypic effects of leptin in an ectotherm: a new tool to study the evolution of life histories and endothermy? J. exp. Biol., 203: 295-300.

Palmert, M.R., Radovick, S. and Boepple, P.A., 1998. Leptin levels in children with central precocious puberty. J. clin. Endocrinol. Metab., 83: 22602265. https://doi.org/10.1210/jc.83.7.2260

Paolucci, M., Buono, S., Sciarrillo, R. and Putti, R., 2006. Effects of leptin administration on the endocrine pancreas and liver in the lizard Podarcis sicula. J. exp. Zool., 305: 383-395. https://doi. org/10.1002/jez.a.284

Paolucci, M., Rocco, M. and Varricchio, E., 2001. Leptin presence in plasma, liver and fat bodies in the lizard Podarcis sicula fluctuations throughout the reproductive cycle. Life Sci., 69: 2399-2408. https://doi.org/10.1016/S0024-3205(01)01326-1

Putti, R., Varricchio, E., Gay, F., Elena, C. and Paolucci, M., 2009. Leptin effects on testis and epididymis in the lizard Podarcis sicula, during summer regression. Gen. Comp. Endocrinol., 160: 168-175. https://doi.org/10.1016/j.ygcen.2008.11.010

Rago, V., Aquila, S., Guido, C. and Carpino, A., 2009. Leptin and its receptor are expressed in the testis and in the epididymis of young and adult pigs. Anat. Rec. (Hoboken), 292: 736-745. https://doi. org/10.1002/ar.20880

Russo, F., De Girolamo, P., Neglia, S., Gargiulo, A., Arcamone, N., Gargiulo, G. and Varricchio, E., 2010. Immunohistochemical and immunochemical characterization of the distribution of leptin-like proteins in the gastroenteric tract of two teleosts (Dicentrarchus labrax and Carassius auratus) with different feeding habits. Microscop. Res. Tech., 74: 714-719. https://doi.org/10.1002/jemt.20948

Sarkar, M., Schilffarth, S., Schams, D., Meyer, H.H. and Berisha, B., 2010. The expression of leptin and its receptor during different physiological stages in the bovine ovary. Mol. Reprod. Dev., 77: 174-181. https://doi.org/10.1002/mrd.21129

Scaramuzzi, R.J. and Martin, G.B., 2008. The importance of interactions among nutrition, seasonality 
and socio-sexual factors in the development of hormone-free methods for controlling fertility. Reprod. Domest. Anim., 43: 129-136. https://doi. org/10.1111/j.1439-0531.2008.01152.x

Sciarrillo, R., Virgilio, F., De Falco, M., Laforgia, V., Varano, L. and Paolucci, M., 2005. Localization and role of leptin in the thyroid gland of the lizard Podarcis sicula (Reptilia, Lacertidae). J. exp. Zool., 303: 628-634. https://doi.org/10.1002/jez.a.196

Shklyaev, S., Aslanidi, G., Tennant, M., Prima, V., Kohlbrenner, E., Kroutov, V., CampbellThompson, M., Crawford, J., Shek, E.W., Scarpace, P.J. and Zolotukhin, S., 2003. Sustained peripheral expression of transgene adiponectin offsets the development of diet induced obesity in rats. Proc. natl. Acad. Sci. U.S.A., 100: 14217-14222. https:// doi.org/10.1073/pnas.2333912100

Sinha, M.K. and Caro, J.F., 1998. Clinical aspects of leptin. Vit. Horm., 54: 1-30. https://doi.org/10.1016/ S0083-6729(08)60919-X

Smith-Kirwin, S.M., O’Connor, D.M., De Johnston, J., Lancey, E.D., Hassink, S.G. and Funanage, V.L., 1998. Leptin expression in human mammary epithelial cells and breast milk. J. clin. Endocrinol. Metab., 83: 1810-1813. https://doi.org/10.1210/ jcem.83.5.4952

Sobhani, I., Bado, A., Vissuzaine, C., Buyse, M., Kermorgant, S., Laigneau, J.P., Attoub, S., Lehy, T., Henin, D., Mignon, M. and Lewin, M.J., 2000. Leptin secretion and leptin receptor in the human stomach. Gut, 47: 178-183. https://doi.org/10.1136/ gut.47.2.178

Spanovich, S., Niewiarowski, P.H. and Londraville, R.L., 2006. Seasonal effects on circulating leptin in the lizard Sceloporus undulatus from two populations. Comp. Biochem. Physiol., 143: 507513. https://doi.org/10.1016/j.cbpb.2006.01.001

Stephens, T.W., Basinski, M., Bristow, P.K., BueVallesky, J.M., Burgett, S.G., Craft, L., Hale, J., Hoffman, J., Hsiung, H.M., Kriauciunas, A., Mackellar, W., Rosteck, P.R.Jr., Schoner, B., Smith, D., Tinsley, F.C., Zhang X.Y. and Heiman, M., 1995. The role of neuropeptide $Y$ in the antiobesity action of the obese gene product. Nature, 377: 530532. https://doi.org/10.1038/377530a0

Sun, H., Zuo, X., Sun, L., Yan, P., Zhang, F., Xue, H., Li, E., Zhou, Y., Wu, R. and Wu, X., 2018. Insights into the seasonal adaptive mechanisms of Chinese alligator (Alligator sinensis) from transcriptomic analyses. Aust. J. Zool., 66: 93-102. https://doi. org/10.1071/ZO18005

Taildeman, J., Demetter, P., Rottiers, I., Holtappels, G., Bachert, C., Cuvelier, C.A. and Pérez-Novo, C.A., 2010. Identification of the nasal mucosa as a new target for leptin action. Histopathology, 56: 789-798. https://doi.org/10.1111/j.13652559.2010.03552.x

Tartaglia, L.A., Demdski, M., Weng, X., Deng, N., Culpepper, J., Devos, R., Richards, G.J., Campfield, L.A., Clark, F.T., Deeds, J., Muri, C., Sanke, S., Moriarty, A., Moore, K.J., Smutko, J.S., Mays, G.G., Woolf, E.A., Monroe, C.A. and Tepper, R.I., 1995. Identification and expression cloning of a leptin receptor, OB-R. Cell, 83: 1263-1271. https:// doi.org/10.1016/0092-8674(95)90151-5

Van der Spuy, Z.M., 1985. Nutrition and reproduction. Clin. Obstet. Gynaecol., 12: 579-604.

Wang, J., Liu, R., Hawkins, M., Barzilai, N. and Rossetti, L., 1998. A nutrient-sensing pathway regulates leptin gene expression in muscle and fat. Nature, 393: 684-688. https://doi.org/10.1038/31474

Wang, R.P., Zhou, Y.J., Wang, C.L. and Ye, R.Q., 1998. The relationship between the environment temperature and the life habits of the Chinese alligator (Alligator sinensis). Chin. J. Zool., 33: 3335.

Watanobe, H., 2002. Leptin directly acts within the hypothalamus to stimulate gonadotropinreleasing hormone secretion in vivo in rats. $J$. Physiol., 545: 255-268. https://doi.org/10.1113/ jphysiol.2002.023895

Zhang, F., Li, Y. and Guo, Z., 2009. Climate warming and reproduction in Chinese alligators. Anim. Conserv., 12: 128-137. https://doi.org/10.1111/ j.1469-1795.2009.00232.x

Zhang, Y., Olbort, M., Schwarzer, K., NuessleinHildesheim, B., Nicolson, M., Murphy, E., Kowalski, T.J., Schmidt, I. and Leibel, R.L., 1997. The leptin receptor mediates apparent autocrine redulation of leptin gene expression. Biochem. biophys. Res. Commun., 240: 492-495. https://doi. org/10.1006/bbrc.1997.7622

Zhang, Z.Q. and Wang, D.H., 2007. Seasonal changes in thermogenesis and body mass in wild Mongolian gerbils (Meriones unguiculatus). Comp. Biochem. Physiol. Pt. A, 148: 346-353. https://doi. org/10.1016/j.cbpa.2007.05.012 